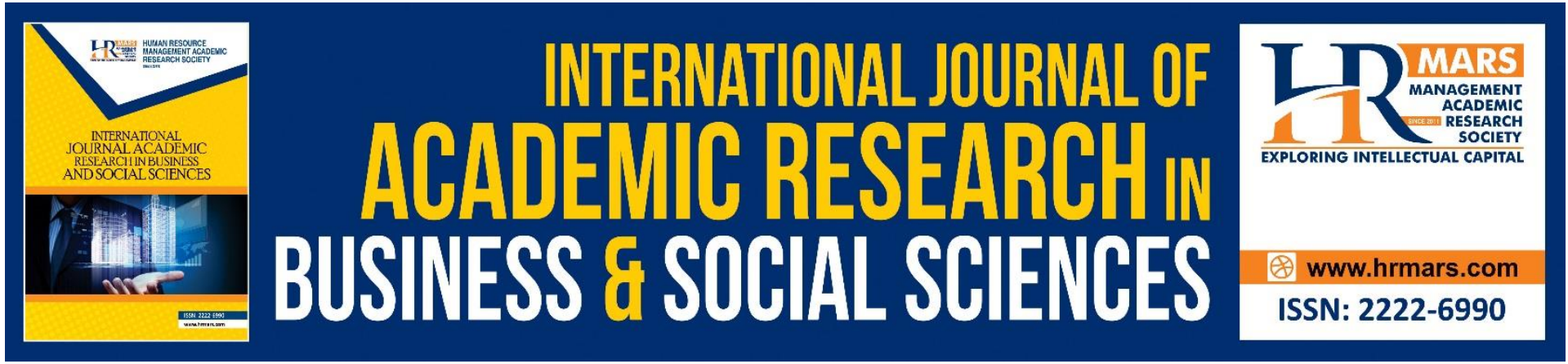

\title{
Language Learning Strategies Applied by Primary Pupils From A Suburban School Are in Improving their Speaking Skills
}

Samantha Jata Anak Robin, Annie Tiong Nii, Genevieve Anak Richard Sandak, Michelle Ting Lik Chiew, Mohd Nur Hirzhan Bin Noordan, Harwati Hashim

To Link this Article: http://dx.doi.org/10.6007/IJARBSS/v11-i6/10191

DOI:10.6007/IJARBSS/v11-i6/10191

Received: 19 April 2021, Revised: 21 May 2021, Accepted: 05 June 2021

Published Online: 21 June 2021

In-Text Citation: (Robin et al., 2021)

To Cite this Article: Robin, S. J. A., Nii, A. T., Sandak, G. A. R., Chiew, M. T. L., Noordan, M. N. H. Bin, \& Hashim, H. (2021). Language Learning Strategies Applied by Primary Pupils From A Suburban School Are in Improving their Speaking Skills. International Journal of Academic Research in Business and Social Sciences, 11(6), 1806-1826.

\section{Copyright: @ 2021 The Author(s)}

Published by Human Resource Management Academic Research Society (www.hrmars.com)

This article is published under the Creative Commons Attribution (CC BY 4.0) license. Anyone may reproduce, distribute, translate and create derivative works of this article (for both commercial and non-commercial purposes), subject to full attribution to the original publication and authors. The full terms of this license may be seen at: http://creativecommons.org/licences/by/4.0/legalcode

Vol. 11, No. 6, 2021, Pg. 1806 - 1826

Full Terms \& Conditions of access and use can be found at http://hrmars.com/index.php/pages/detail/publication-ethics 


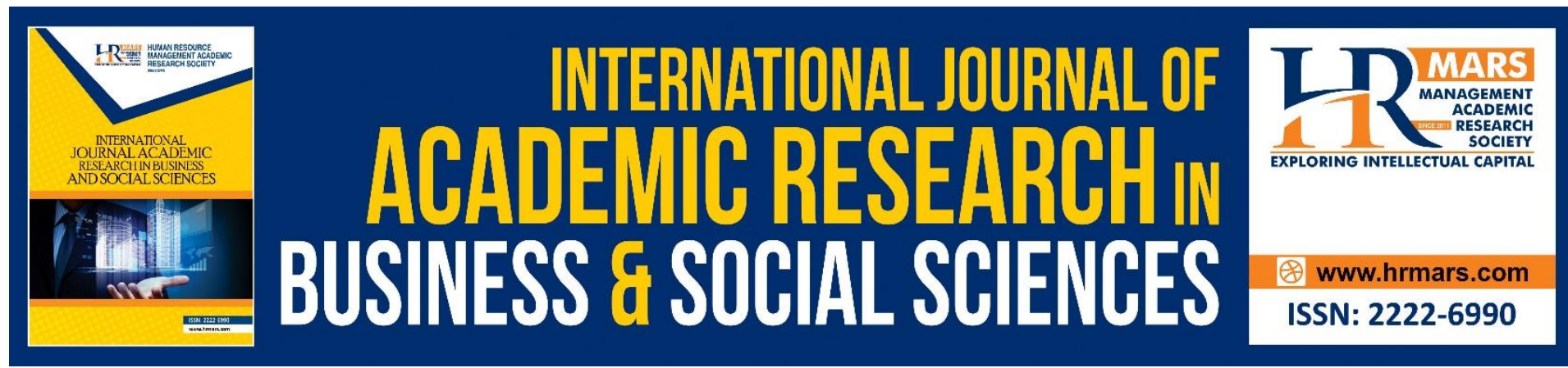

\title{
Language Learning Strategies Applied by Primary Pupils From A Suburban School Are in Improving their Speaking Skills
}

\author{
Samantha Jata Anak Robin, Annie Tiong Nii, Genevieve Anak \\ Richard Sandak, Michelle Ting Lik Chiew, Mohd Nur Hirzhan \\ Bin Noordan, Harwati Hashim
}

Faculty of Education, Universiti Kebangsaan Malaysia

Email: samanthajatarobin@gmail.com

\begin{abstract}
Pupils have different ways of learning the English Language. It is important for teachers to be able to identify pupils' application of learning strategies. This enables teachers to better craft lessons depending on the pupils' needs in order to maximise the language learning process in the classroom. Language Learning Strategies (LLS) is the key factor in putting together the needed aid in the English Language Learning. It aids learners during their English Language Learning. Thus, study was conducted in a suburban primary school in Kapit, Sarawak to explore the language learning strategies of learners in a suburban primary school. It involved a total of 40 pupils as respondents. Pupils are enthusiastic in learning the English Language apart from their mother tongue. Pupils resolved to other ways of trying to understand the English Language. However, only limited language strategies were employed by learners in this study, for example, translating to their mother tongue, initiating conversation using simple English and using body gestures to convey messages. The findings reveal that pupils are rather enthusiastic in English Language Learning despite the lack of resources and unfavourable environment. Pupils are creative in sorting out ways to learn the English Language.
\end{abstract}

Keywords: Language Learning Strategies (LLS), ESL, Suburban School, Speaking Skills

\section{Introduction}

English is a second language in Malaysia despite being a multiracial country. This dated way back to the 1950s when Malaysia was colonised by British and was granted independence in 1957. Since then, English has become the second most important language to master regardless of learning the language itself in school or a daily conversation during work or with the public. In Malaysia, English is heavily used as a medium of instruction in both formal and informal settings (Haida \& Melor, 2018). The ability to converse in English is very important. In certain states in Malaysia like Sarawak, the English language is used as a medium of 
communication for official matters and civil worker deployment. In an ESL classroom, speaking is a very important skill and always gives a dynamic impression to the listeners (Abdul, 2011). One who does not possess the English communicative competence is branded as illiterate as today's educated man without the knowledge of computers (Abdul, 2011). With the implementation of The Common European Framework Reference (CEFR) in the english syllabus and assessment, the Ministry of Education is making a change in shaping the curriculum in alignment with the global English standard. The focus of the new curriculum placed emphasis on the language learning skills, namely, speaking skills, reading skills, writing skills and listening skills and communicative activities. The implementation is to be able to produce learners that can converse well and eloquently in the English language. Each respective learner has their own different Language Learning Strategies (LLS). The students should be granted the responsibility and freedom to explore their most favourable learning strategies. This will help learners to be able to learn in a fun and interactive way. The different linguistic environment could influence the level of students' vitality in language learning (How, Ain \& Chan, 2017). The Malaysian Education Blueprint emphasizes on the importance English language in schools and introduces many innovative teaching, engaging activities and learning strategies to enhance students' English proficiency (Sidhu, Kaur, \& Chi, 2018).

With the implementation of CEFR in the syllabus and curriculum, the speaking approach is highlighted in the content for teaching and learning. The main aim of CEFR implementation is to produce learners that are able to communicate proficiently in English language. A lot of the time students are able to write a simple piece of short essay however could not speak beyond the needed answers. Students are not able to engage in interesting and opinionated topics and conversations. One of the problems that lead to the students' speaking ability is the lack of opportunity to exercise the language. They do not have enough resources for them to refer to as guidance. Students tend to shy away when they are required to speak in a language apart from their mother tongue. Ler (2012) added that rural and suburban students are inclined to be more shy and reserved when it comes to learning English. Gardner's (1985) highlighted that second language (L2) students who view the target culture in a positive manner will learn the target language more effectively compared to those who perceive the targeted language culture negatively. The perceptions from others discourage them from learning without taking into consideration others' opinions. Students lack intrinsic motivation to learn the English language and only do it for the sake of being told so. Another problem that results in the lack of speaking abilities among learners is the lack of chance to speak outside of the classroom. Pupils in rural and suburban schools barely practice using the English language outside the classrooms and adopt very limited learning strategies to improve their command in the language. Students who are staying in secluded areas normally do not show a positive attitude and enthusiasm towards learning English (Farah \& Abu, 2019). The only time where students can exercise their English speaking skills is during English language lessons. Outside of the English class is considered a luxury if they have the right environment to exercise the language. Therefore, this has led to the widening of the gap between learners in rural and suburban schools.

\section{Research Objectives}

This study is deployed to investigate

1. The language learning strategies of learners in a suburban primary school.

2. The learners' coping ability in speaking skills for English Language Learning. 


\section{Research Questions}

This study intends to answer the following questions:

1. How do pupils cope with their learning in speaking skills?

2. How do pupils improve their speaking skills?

\section{Literature Review}

\section{Student having Problem with Speaking Skills}

The most crucial aspect of communication is language. Language is often used as a tool of communication among nations all over the world. Students need to ace in language as it is vital in their lives. Good speaking skills enable the students to participate in meaningful conversation. This will allow students to convey the messages well with others during discussion. Some students are incapable of speaking English well even though they have used the language in the lesson.

There are a lot of factors that have caused some students to be unable to converse in English well. Heriansyah (2012) stated that the students are not used to converse in English because of the fear that they are judged with weak pronunciation and vocabulary. Students are passive in a discussion most of the time because they have nothing to say. This leads to low participation in a discussion. Low motivation in students to improve their speaking skills due to not being able to understand certain words. Inadequate motivation to speak the English language makes the students lose interest. Lack of confidence to use the English language makes the students feel that they do not need to improve their speaking skills. It is one of the reasons that make students unable to speak English in public.

\section{Developing Speaking Skills in the English Classroom}

Speech is the most effective way to develop other language abilities. Learning a foreign language through speaking is the best alternative. The actual application of a foreign language happens in speech which makes it significant. One of the most vital skills that the students can learn is the oral language, which is crucial for social and academic purposes. Students that are able to utilize this ability are able to comprehend and provide instructions. Making a request, receiving new knowledge will enable the students to connect with peers throughout the day because they have good speaking skills.

Teaching speaking skills to the students is fundamental. Speaking skills is important for career advancement (Parupalli, 2019). This is important to prepare the students' soft skills for job requirements in the future. There are many ways that teachers can use to improve students' speaking skills in the English classroom. Students that have good speaking skills will be able to produce English speech sounds and patterns. The speech sound and patterns will sound clearly uttered by students. This indicates the students are able to use words and sentences stress better. Intonation patterns and the rhythm of the second language also improved better. People will understand better the speech conveyed by speakers. Selecting appropriate words and sentences according to the proper social setting, audience, situation, and subject matter is one way to improve speaking skills. Teachers can help the students to organize their thoughts in a meaningful and logical sequence. It will enable the students to convey the speech better. Using the language to express values and judgments can improve the students' arguments better during discussion. Fluency in English speech will make the students use the language quickly and confidently with little unnatural pauses. 


\section{Language Learning Strategies}

Learning strategy is a specific action, behavior, steps, or techniques used to tackle a problematic language task. Students use it to enhance their learning. It is very prominent that language learning strategies enact an important part in improving the understanding of students' language learning process. Language learning strategy is important for the development of students' second language. Effective implementation of learning strategies will enable the students to complete the target language acquisition process (Noor et al., 2012). Language learning strategies undeniably contribute in increasing students' knowledge of the second language learning process while acquiring all the skills.

The preference of language learning strategies is influenced by factors in the acquisition process. One of the preferences that influence the learner is the level of knowledge, gender, ethnicity, learning style, desire to improve, given a task that will motivate the students to learn the target language. Teachers can assist the students in determining the prominent type of learner. It will be easier for the students to think of the learning strategies that are suitable for them. Understanding the type of learners and Language learning strategies is vital in determining students' academic achievement.

\section{Methodology}

\section{Participants}

The purposive sample selected was 40 participants' ages ranging 11 years old from Year 5 class in a primary school in Kapit, Sarawak. All participation was voluntary and participants were willing to share their language perceptions truthfully during the research. They also understood that the results of the data collection were intended only for research purposes.

\section{Instruments}

The present study employed a survey design applying closed-ended survey questionnaires as the instrument of the study for exploring the students' perceived attitudes on their language learning strategies used by primary school pupils from remote areas to improve speaking skills. To improve the validity of the data and to avoid participants' misunderstanding or failing to fully express their views due to their English proficiency limitations, they were free to use Bahasa Malaysia or English in answering the questions. To receive reliable data, the answers were transcribed and translated. The data were transcribed in Bahasa Malaysia and then translated into English.

Below are the descriptions for each scale for the closed-ended survey questionnaire:

\begin{tabular}{|l|l|}
\hline Scale & Description \\
\hline 1 & I use this strategy and find it useful \\
\hline 2 & I have tried this strategy but I do like to learn it more \\
\hline 3 & I have never tried this strategy \\
\hline
\end{tabular}

Table 1. Descriptions of the scale

\section{Survey Tool of Speaking Strategy Inventory}

The current study adopted Language Strategy Use Inventory created by Cohen and Chi (2006). The purpose of this inventory is to find out more about how learners perceive themselves as 
well as to find out more about themselves as a language learner. This inventory however was adapted by adding the phrase of "I may" along to help participants discover their inner thoughts and perceptions towards their mastery of English language. Each description was inserted along with 'I may' in order to promote a sense of self-efficacy towards the language used. It is a 3-item Likert-scale questionnaire with a reliability coefficient of 0.50 for this study. The learners gave their responses on three-point Likert scales, with the available answers being: I use this strategy and find it useful (1), I have tried this strategy but I do like to learn it more (2)and I have never tried this strategy (3).

The 3-point scale makes it possible to collect more detailed and revealing information. The questionnaire was also piloted using a small group of students with similar characteristics to the participants in the main study. The purpose was to guarantee that the questionnaire covered the strategies related to learning speaking in English and that the students could understand the questionnaire completely when there is also translation of the questionnaire in Bahasa Malaysia. Although the completion of the questionnaire took approximately 30-35 minutes, the researchers informed the participants that there was no fixed time in completing it.

\section{Distribution of Survey through Google Forms}

Google Forms is a web-based app used to create forms for data collection purposes. In this study, we create Google Forms for students to do a survey in order to collect their feedback. The form is web-based and therefore can be shared with respondents by sending a link and emailing a message. Data gathered using the form is thereby administered and stored in a spreadsheet.

\section{Findings \& Discussion}

Improving speaking skills is not easy for learners, especially young learners in primary schools. Thus, a close-ended survey questionnaire had been developed to identify how pupils cope with their learning and improve their speaking skills. It consists of three sections which are;

I. In order to practice for speaking

II. In order to engage in conversation

III. When I can't think of a word or expression

First section is "In order to practice for speaking."

\section{I may well say new expressions repeatedly to myself in order to practice them (Saya mungkin mengatakan ungkapan baru berulang kali kepada diri sendiri untuk mempraktikkannya/berlatih) 40 responses}

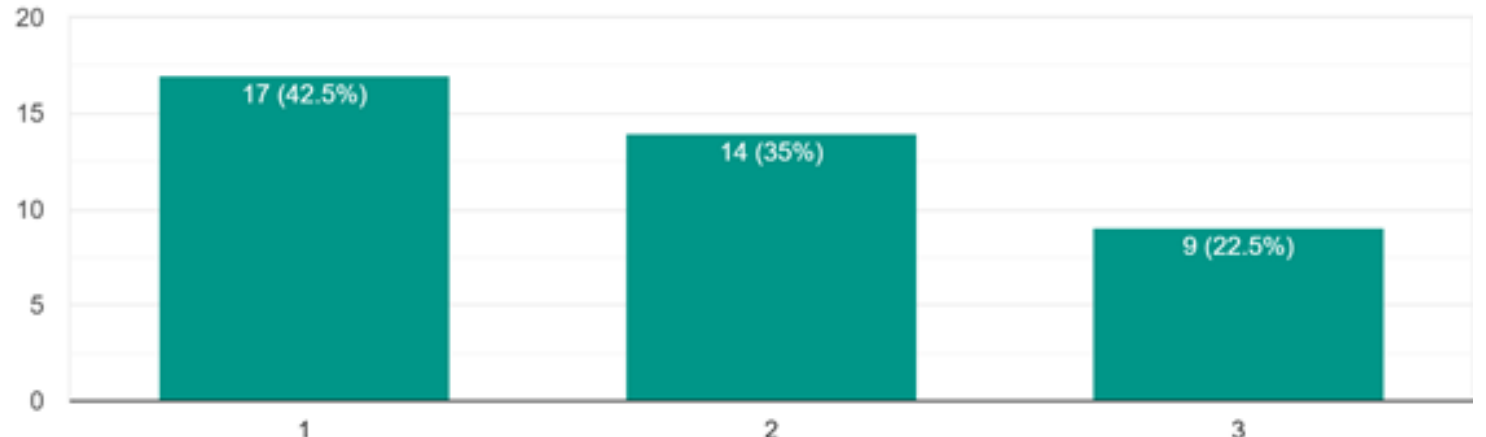


Figure 1. Say new expressions repeatedly

Figure 1 shows $42.5 \%$ of the participants which is the majority use the strategy in improving their speaking skill. Meanwhile, $35 \%$ of the participants have tried the strategy but they want to learn more and $22.5 \%$ have never tried the strategy. Repetition fixes new words in their memory. Thus, they prefer to repeat the new words they obtain and use it directly as a practice. Rapid learning of new words is crucial for language acquisition, and frequent exposure to spoken words enables vocabulary development (Kimppa, 2017).

\section{I am likely to practice new grammatical structures in different situations to check out my confidence level with the structures (Saya cender...ui tahap keyakinan saya dengan struktur tersebut) 40 responses}

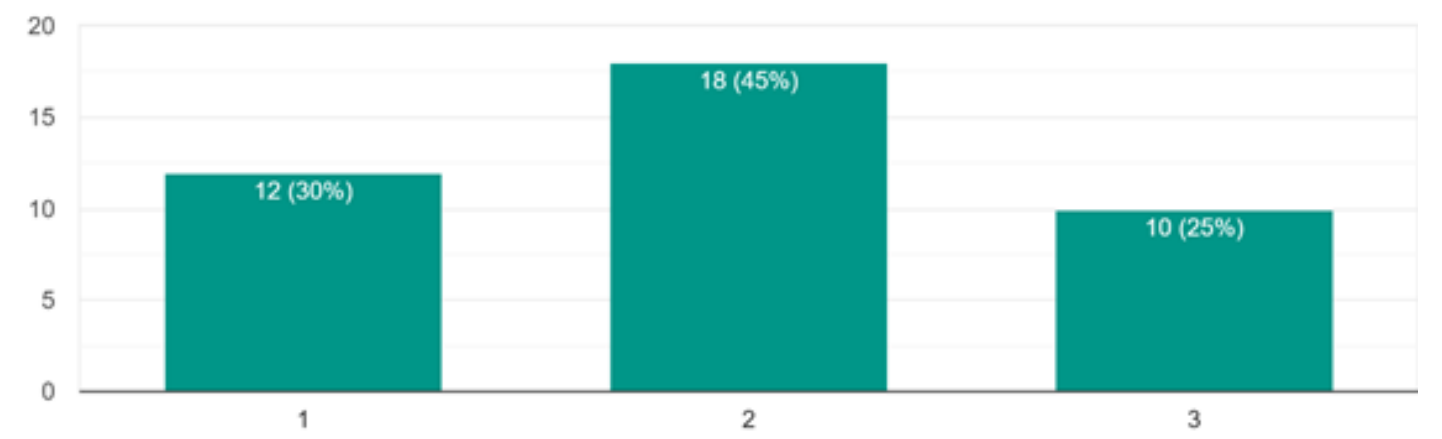

Figure 2. Practice new grammatical structures in different situations

Figure 2 shows the majority of the participants (45\%) have tried the strategy of practicing new grammatical structures in different situations and want to learn more about it. Meanwhile, only 12 participants use the strategy and a minority of them have never tried the strategy.

3. I ask myself how a native speaker might say something and I attempt to practice saying it that way (Saya bertanya pada diri sendiri bagaimana pe...an saya cuba berlatih mengatakannya seperti itu) 40 responses

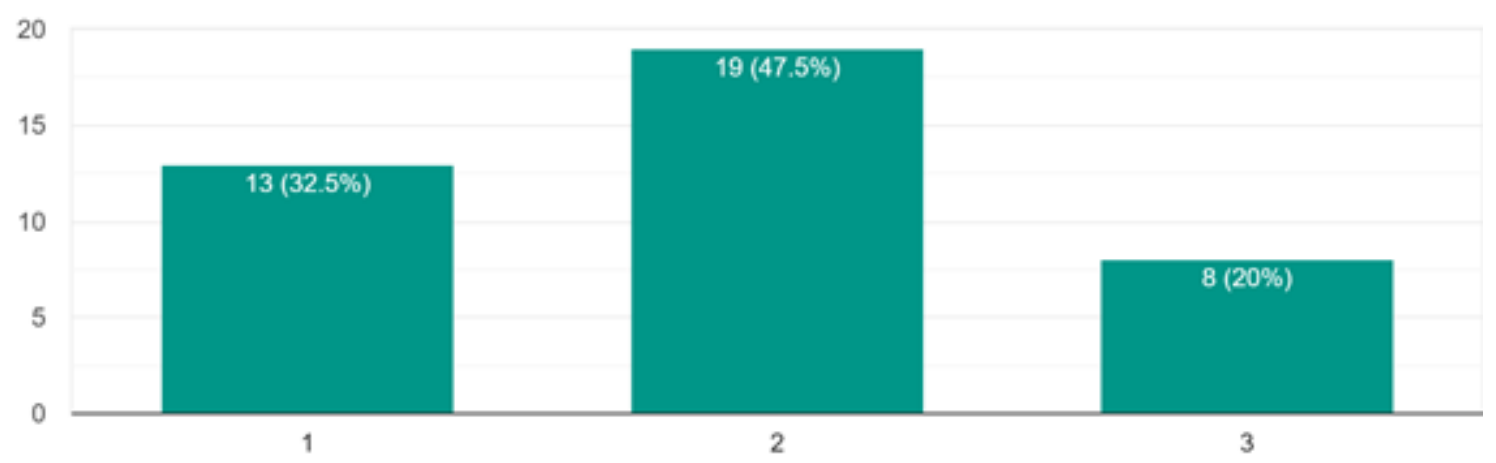

Figure 3. Ask themselves and attempt to say something how a native speaker does Figure 3 shows the majority, $47.5 \%$ have tried the strategy where they attempted to practice saying something as a native speaker does and they still want to learn it. Meanwhile, $13 \%$ of the participants used the strategy and they found it useful to improve their speaking skill. Only $20 \%$ of the participants have never tried the strategy. 


\section{I regularly seek out people with whom I can speak the new language (Saya biasanya mencari orang yang boleh berbual dengan saya menggunakan bahasa baharu tersebut) 40 responses}

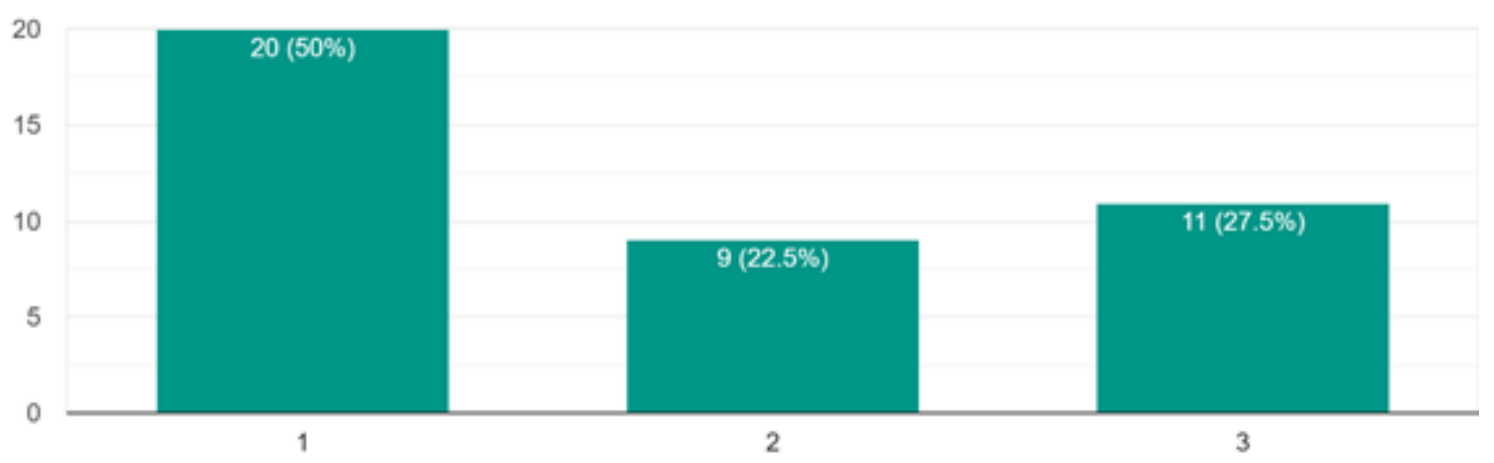

Figure 4. Seek out people with whom they can speak the new language

Figure 4 shows half of the participants $(50 \%)$ seek out people with whom they can speak the new language and found the strategy is useful. It also showed that only $11 \%$ of the participants have never tried the strategy and a minority of them $(22.5 \%)$ have tried the strategy but they still want to learn the strategy. By having a conversation with the native speaker, participants can enhance their speaking skill in the target language better (Fumiko Nishimura and Keiko Umeda, n.d.).

\section{I initiate conversations in the new language as often as I can (Saya memulakan perbualan dalam bahasa baru sekerap yang saya boleh) \\ 40 responses}

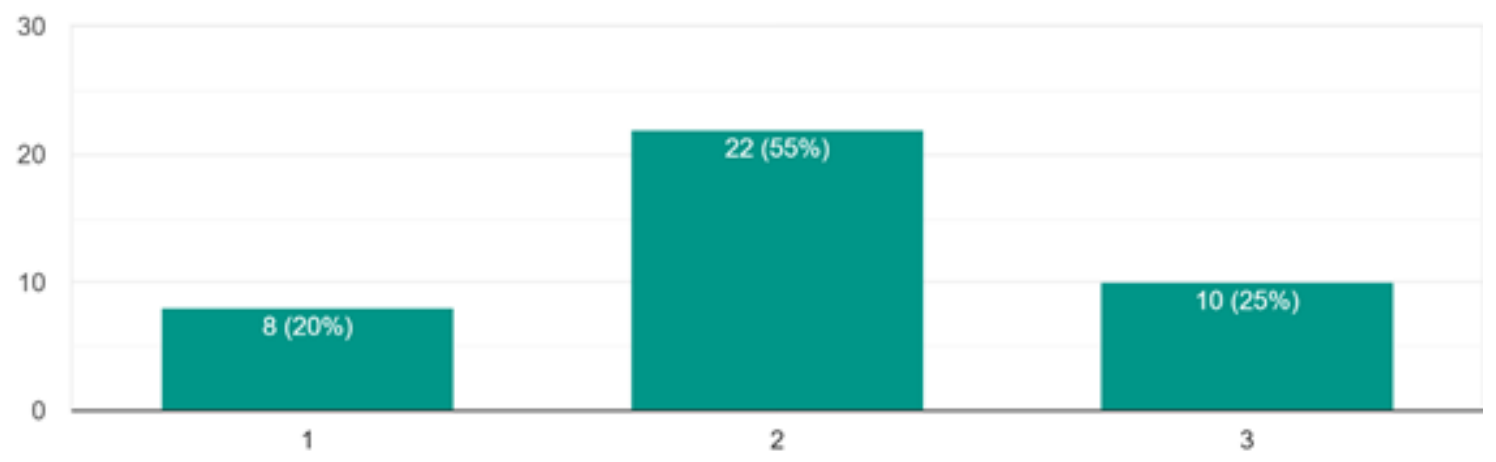

Figure 5. Initiate conversations in the new language

Figure 5 shows the majority of the participants (55\%) have tried to initiate conversations in the new language in order to improve their speaking skill but they still want to learn the strategy more. Meanwhile, there are $25 \%$ of them who never tried to initiate conversations in the new language. The graph shows only the minority $(20 \%)$ have tried the strategy and find it useful. 


\section{I frequently direct the conversation to topics for which I know vocabulary (Saya sering mengarahkan perbualan ke topik yang saya tahu perbendaharaan kata) \\ 40 responses}

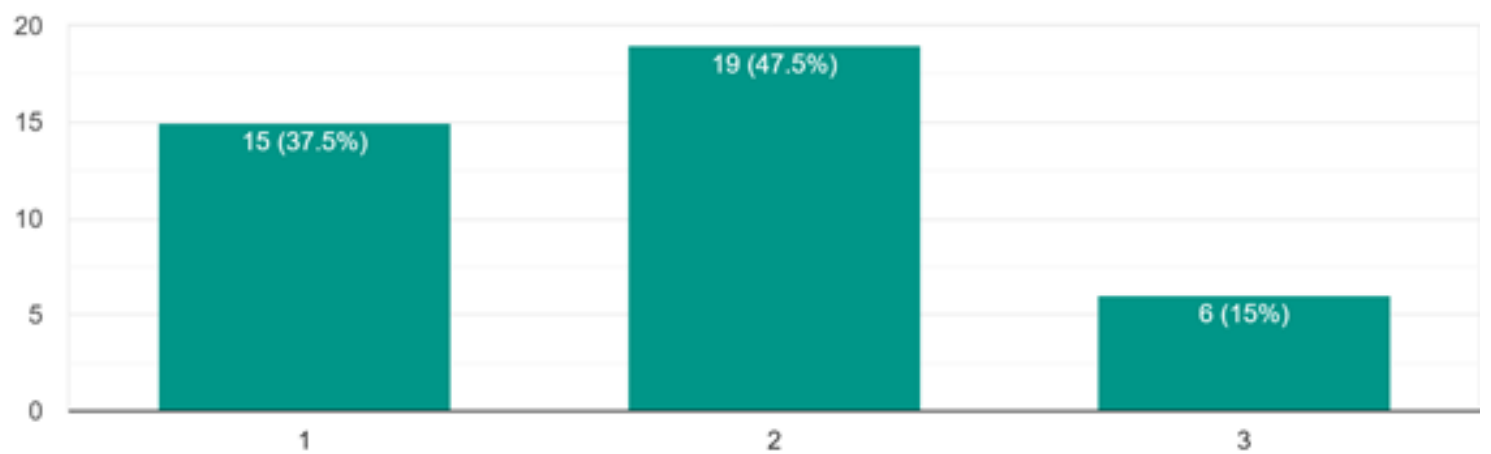

Figure 6. Direct the conversation to topic for which they know vocabulary

Figure 6 shows the majority of the participants, $47.5 \%$ have tried to direct the conversation to a topic in which they know vocabulary and still want to learn it that way. In the meantime, $37.5 \%$ of the participants have tried the strategy and they found it useful for them. Only $15 \%$ or 6 participants have never tried to use the strategy in order to improve their speaking skill.
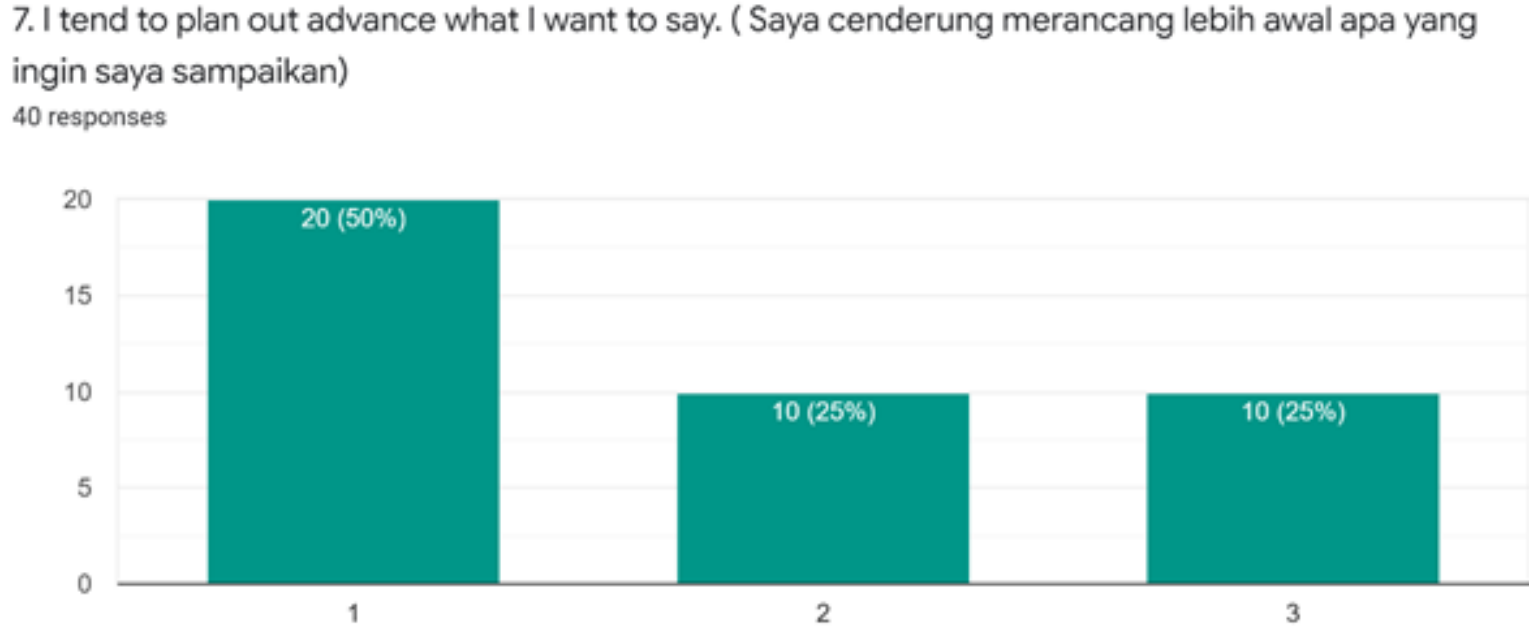

Figure 7. Plan out advance what to say

Figure 7 shows the majority or half of the participants (50\%) plan out advance what they want to say in conversing with people. Meanwhile, $25 \%$ of the participants have tried the strategy but still want to learn it more and $25 \%$ also never tried the strategy. 


\section{I frequently ask questions as a way to be sure I am involved in conversation (Saya sering mengemukakan soalan sebagai cara untuk memastikan saya terlibat dalam perbualan) 40 responses}

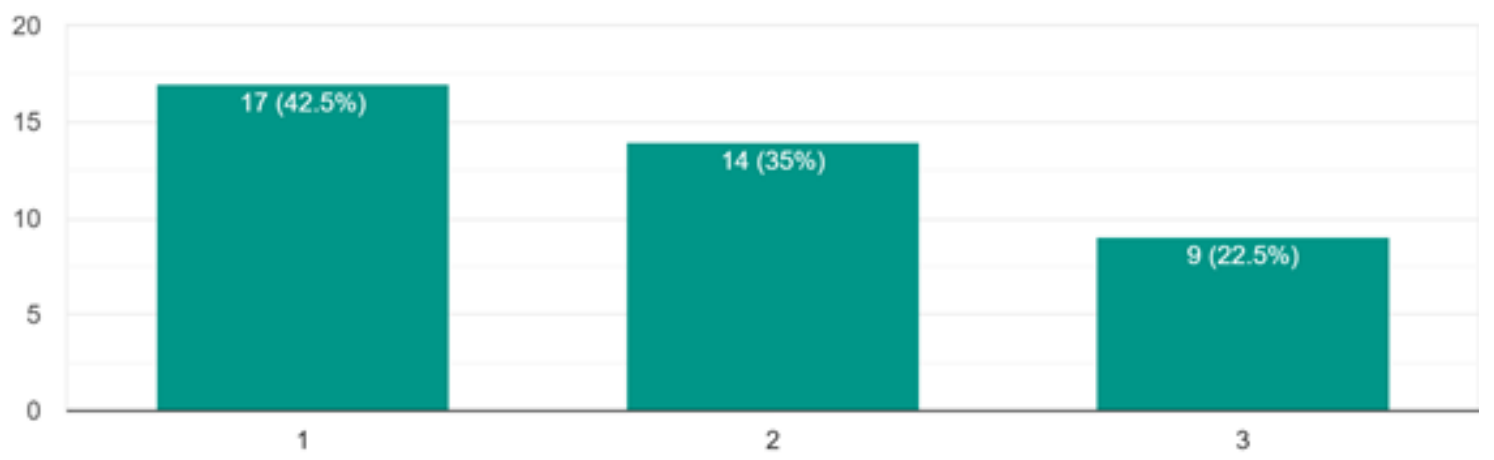

Figure 8. Ask questions as a way to be sure involved in conversation

Figure 8 shows $42.5 \%$ of the participants which is the majority of them have tried the strategy and found it useful for them. They ask questions while having a conversation with people to make sure that they are involved in the conversation. In the meantime, $35 \%$ of the participants have tried the strategy but want to learn it more and least of them (22.5\%) have never tried the strategy.

\section{I anticipate what other person is going to say based on what has been said so far. (Saya menjangkakan apa yang akan disampaikan oleh oran...asarkan apa yang telah diperkatakan selama ini) 40 responses}

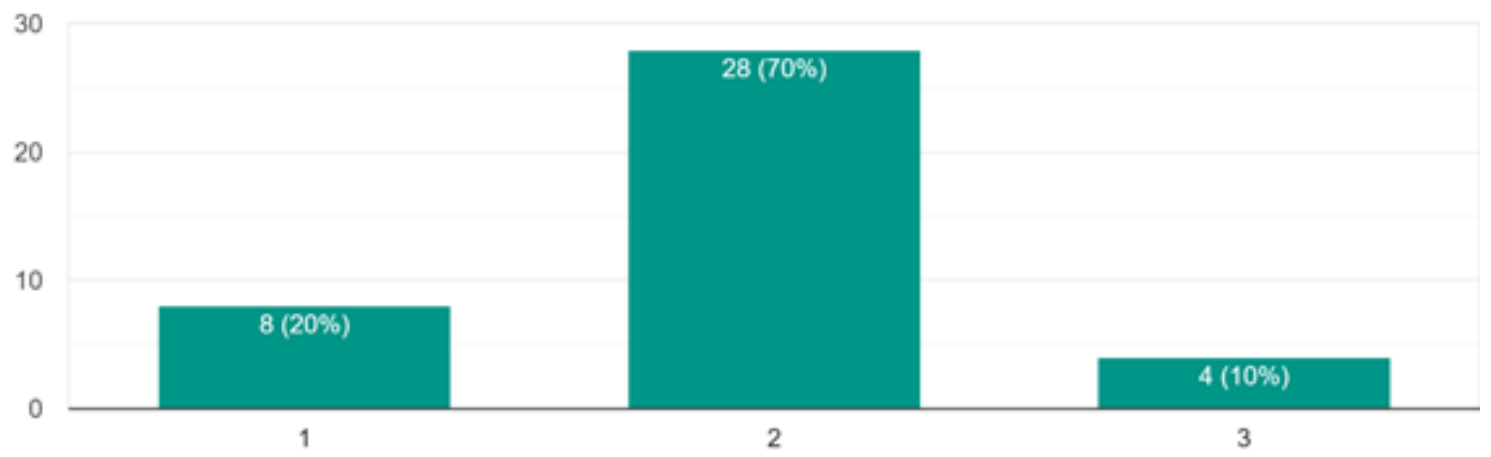

Figure 9. Anticipate what other person is going to say

Figure 9 shows the majority of the participants, 70\% which is a high percentage can anticipate what another person is going to say based on what has been discussed so far but they still want to learn it more on the strategy. Meanwhile, $20 \%$ of the participants used the strategy and they found it useful for them. Only $10 \%$ of the participants have never tried to use the strategy. 
10. I usually avoid topics I don't have language for. (Saya biasanya mengelakkan topik yang saya tidak mempunyai bahasa untuknya)

40 responses

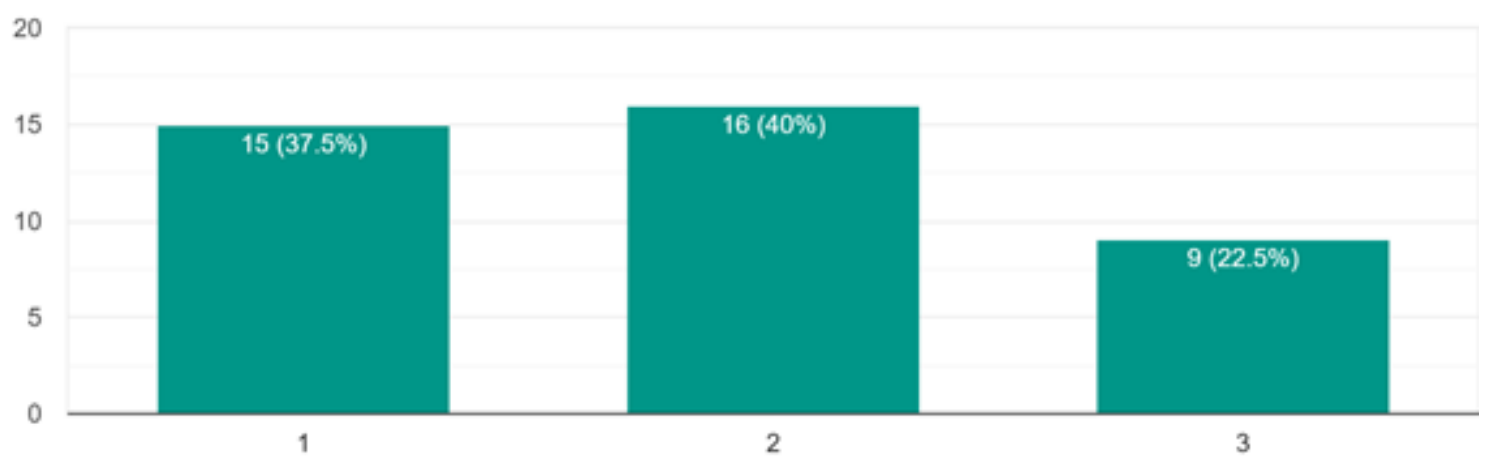

Figure 10. Avoid topics they don't have language for

Figure 10 shows very high percentages on avoiding the topics they don't have language for where $37.5 \%$ and $40 \%$ actually do it. Only $22.5 \%$ have never tried the strategy. Participants tend to avoid any topic which they do not have language to express as they have low vocabulary on it. Thus, they think it is safer for them to just avoid the topic during conversation.

\section{I often look to others to correct my errors in speaking and welcome the feedback (Saya sering meminta orang lain untuk membetulkan kesalahan ...etika bercakap dan menerima baik maklum balas) 40 responses}

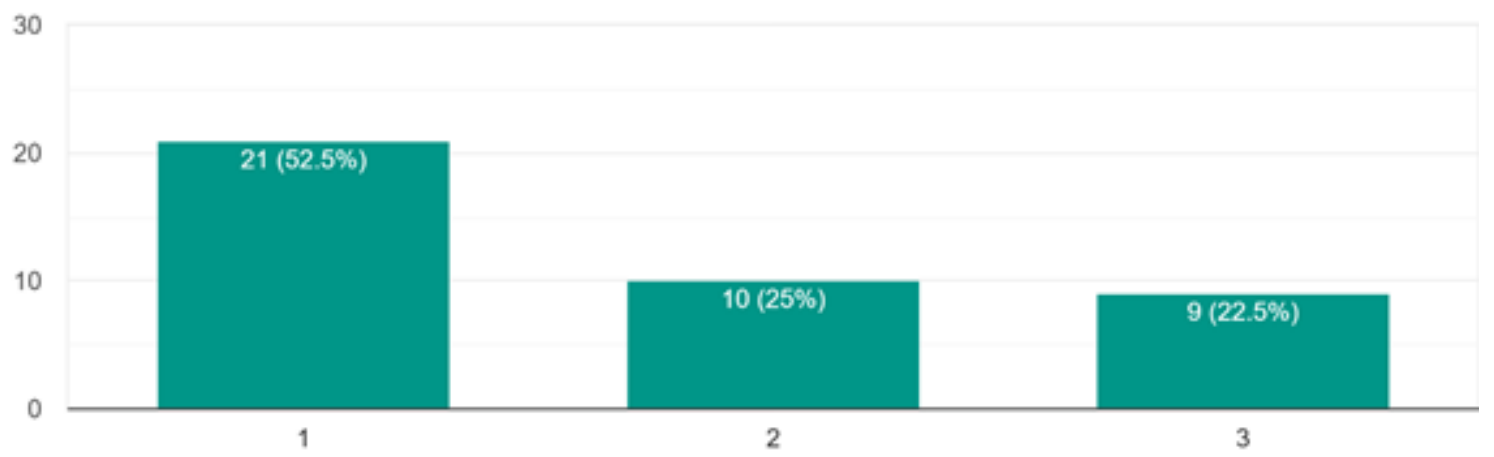

Figure 11. Look others to correct their errors in speaking and welcoming the feedback

Figure 11 shows only $52.5 \%$ of the participants have tried to look others to correct their errors in speaking and welcoming the feedback they get. They found it was useful for them in improving their speaking skill. On the other hand, $25 \%$ of the participants have tried the strategy and they still want to learn more in order to improve their speaking skill. The least percentage is $22.5 \%$ where the participants never tried the strategy. 
12. I frequently use expressions that call for both language and cultural knowledge, such as requesting, apologizing or complaining in the ta...aaf atau mengeluh/merungut dalam bahasa sasaran) 40 responses

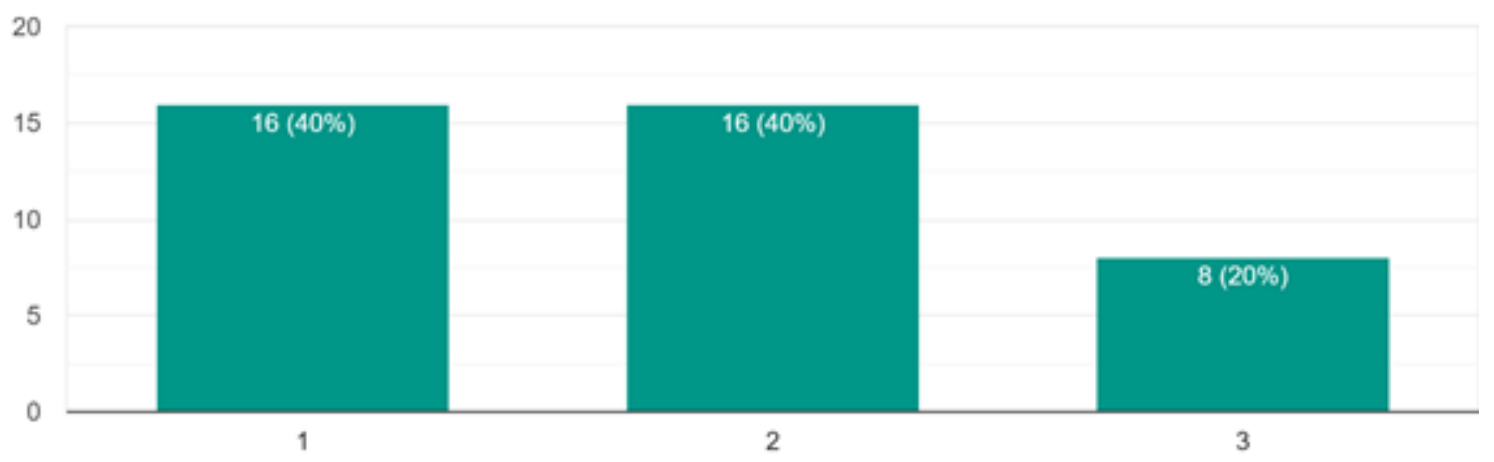

Figure 12. Use expressions for both language and cultural knowledge

Figure 12 shows $40 \%$ of the participants used the strategy and they found it useful. They use expressions that call for both language and cultural knowledge such as requesting, apologizing or complaining in the target language. Meanwhile, $40 \%$ of the participants too have tried the strategy but they still want to learn it more. Only a few of them with $20 \%$ have never tried the strategy. For example, the participants can simply complain such as "so tired!" even though English is not their mother tongue but the target language.

\section{If I don't know how to perform culturally-based language expressions such as apologizing, I sometimes ask natives what they do (Sekiranya sa...nya kepada penutur asli apa yang mereka lakukan) 40 responses}

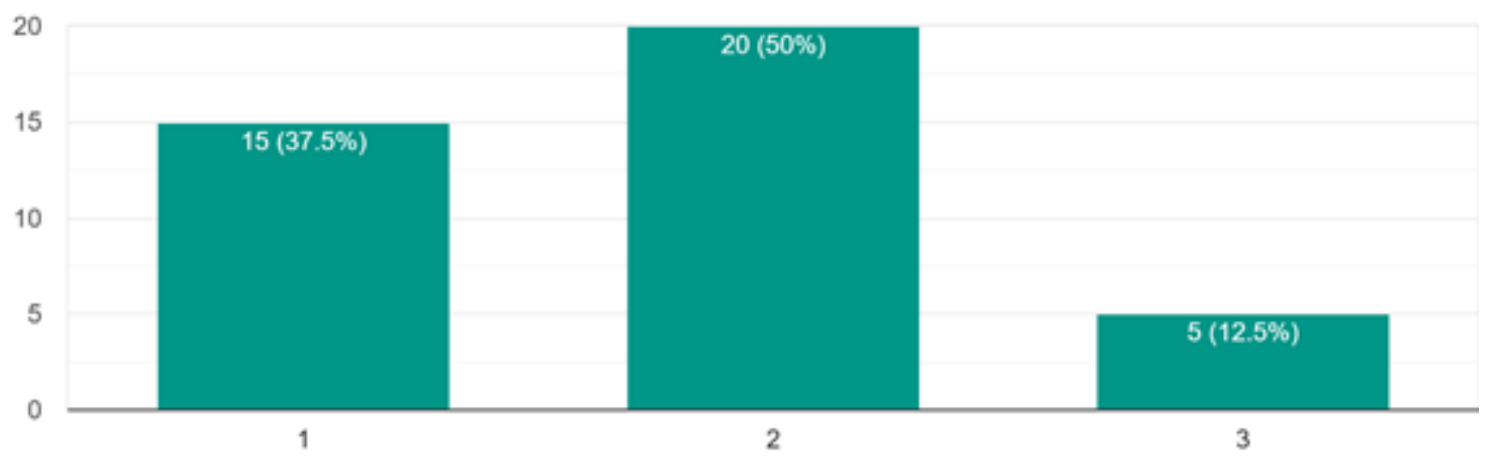

Figure 13. Ask natives what they do to perform cultural-based language expressions

Figure 13 shows the majority of the participants (50\%) have tried to ask natives what they do to perform cultural-based language expressions such as apologizing and they want to learn more. $37.5 \%$ have used the strategy in improving their speaking skill and they found it was useful. Only $12.5 \%$ participants have not tried the strategy. The participants show a positive act where they tend to ask the native speaker on how to say the specific words in order to learn them. 
Third section is "When I can't think of a word or expression."
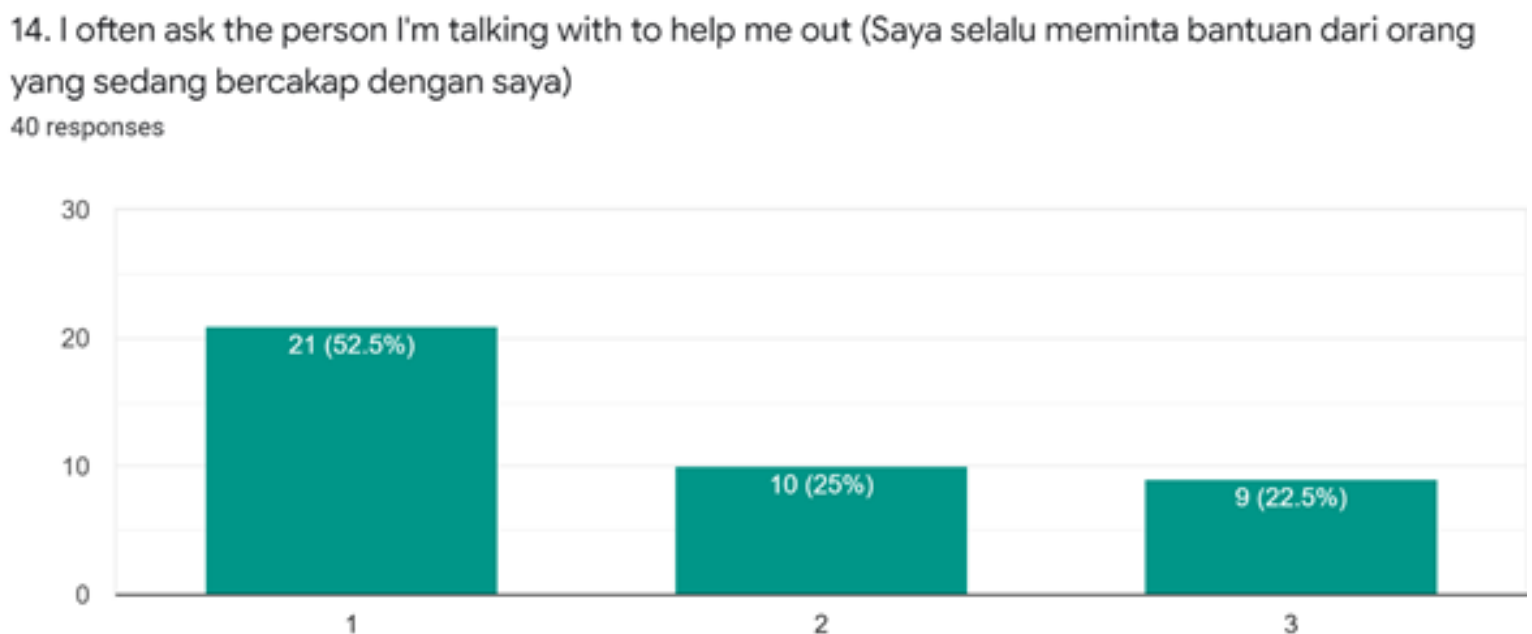

Figure 14. Ask the person they talk with to help out

Figure 14 shows the majority of the participants (52.5\%) have used the strategy where they often ask the person they talk with to help them out during a conversation and they found it was useful. Meanwhile, $25 \%$ of the participants have tried to use the strategy but they still want to learn more. Only $22.5 \%$ of the participants have never tried to use the strategy. After getting the help, the participants indirectly can learn how to convey their message in the right language. Instead of avoiding to talk, they ask the person whom they talk with to help.

15. I will look for different way to express the idea; for example, I use a synonym or describe the idea or object I want to talk about (Saya akan men...ngkan idea atau objek yang ingin saya bincangkan) 40 responses

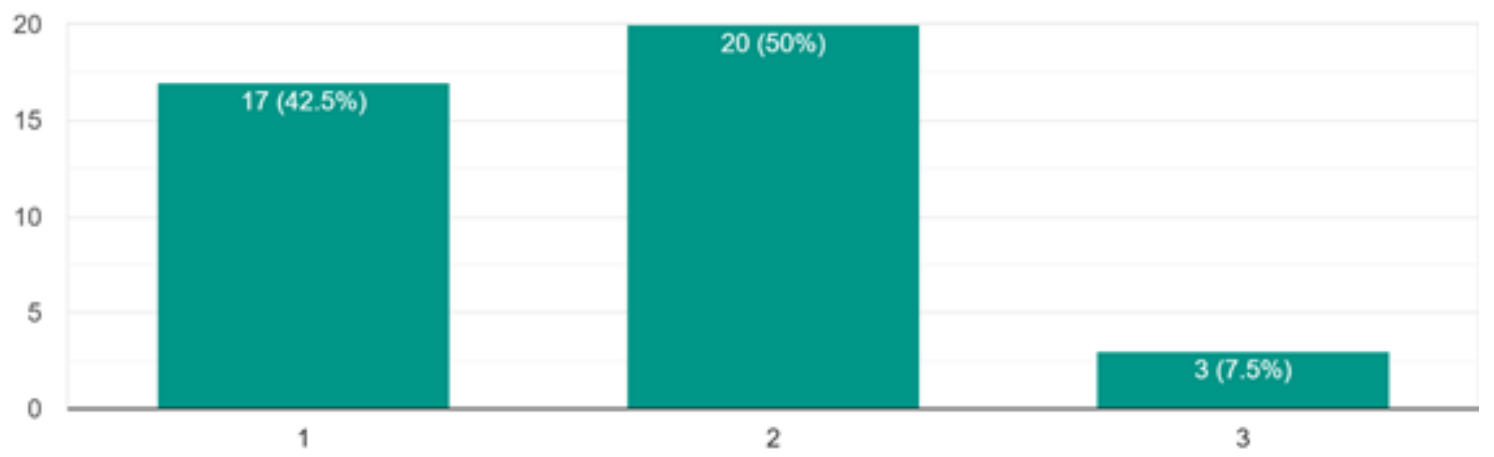

Figure 15. Look for different way to express the idea

Figure 15 shows $50 \%$ of the participants have tried to look for different ways to express their idea but they still want to learn it more. They use the same words of synonym to describe their idea or an object. Meanwhile, $42.5 \%$ of the participants have tried to do so and they found it useful for them. Only $7.5 \%$ of the participants, which is only 3 out of 40 , have never tried the strategy. By looking at other ways to express their idea shows how participants try to be creative with their words. They are not limiting their vocabulary and use words they know. 
16. I use words from my native language, but I add vowels or consonants so that they seem like words in the target language (Saya menggunakan k...lihatan seperti perkataan dalam bahasa sasaran) 40 responses

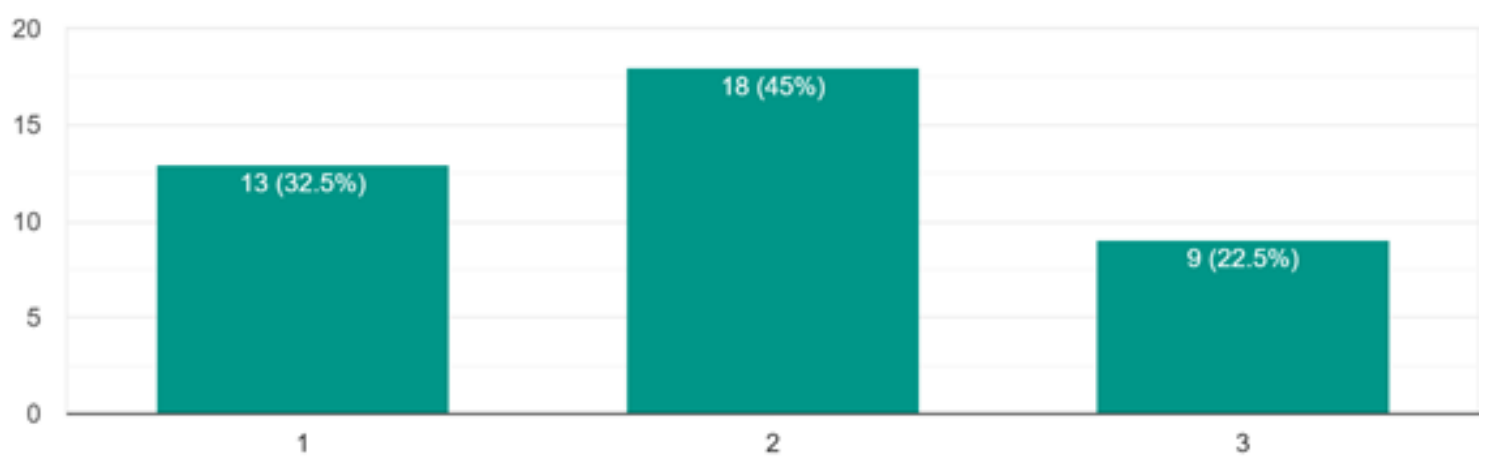

Figure 16. Use their native language by adding vowels and consonants to seem like in the target language

Figure 16 shows $45 \%$ of the participants did use their native language by adding vowels and consonants so that they seem like words in the target language but they still want to learn it more. $32.5 \%$ of the participants have used the strategy and found it was useful to improve their skill in speaking the target language. Few participants, $22.5 \%$ have never tried the strategy.

\section{On occasion I may make up new words if I do not know the right ones (Saya akan membuat perkataan baharu jika saya tidak tahu yang betul) \\ 40 responses}

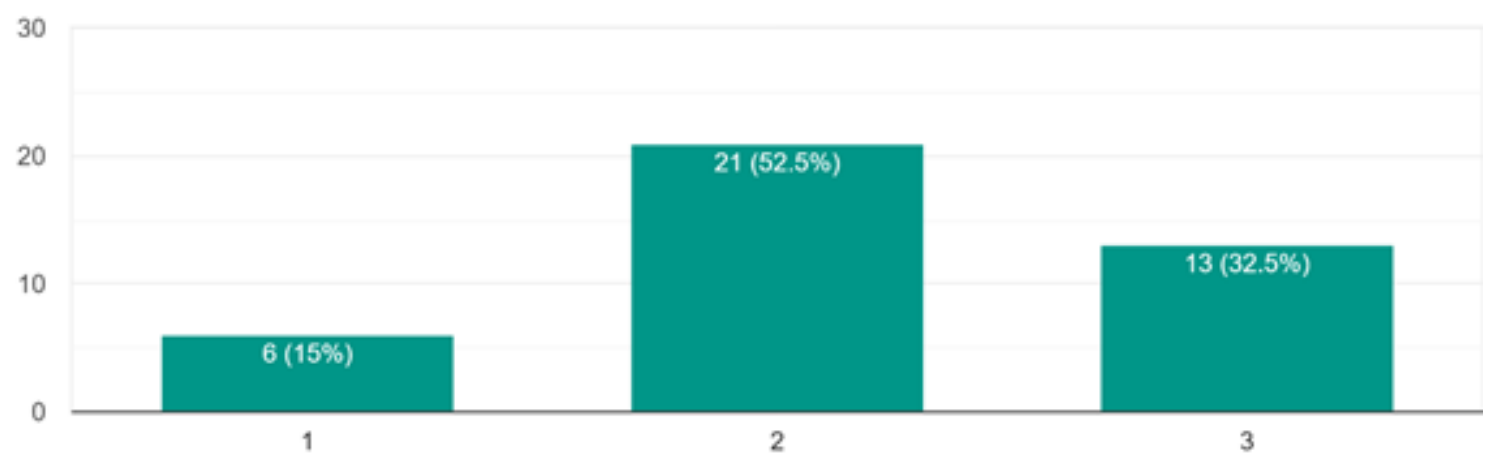

Figure 17. Making up new words when do not know the right ones

Figure 17 shows the majority of the participants prefer to make up words when they do not know the particular words but they still want to learn more about the strategy. Meanwhile, more of them have never used the strategy which is $32.5 \%$ compared to the $15 \%$ who have tried that strategy and found it very useful for improving their speaking skill. This situation frequently happens when participants could not find the right one but use the word 'phew' instead of 'fatigue'. 
18. Whenever necessary I use gestures as a way of conveying my meaning (Bila perlu, saya akan menggunakan pergerakan badan untuk menyampaikan apa yang saya maksudkan) 40 responses

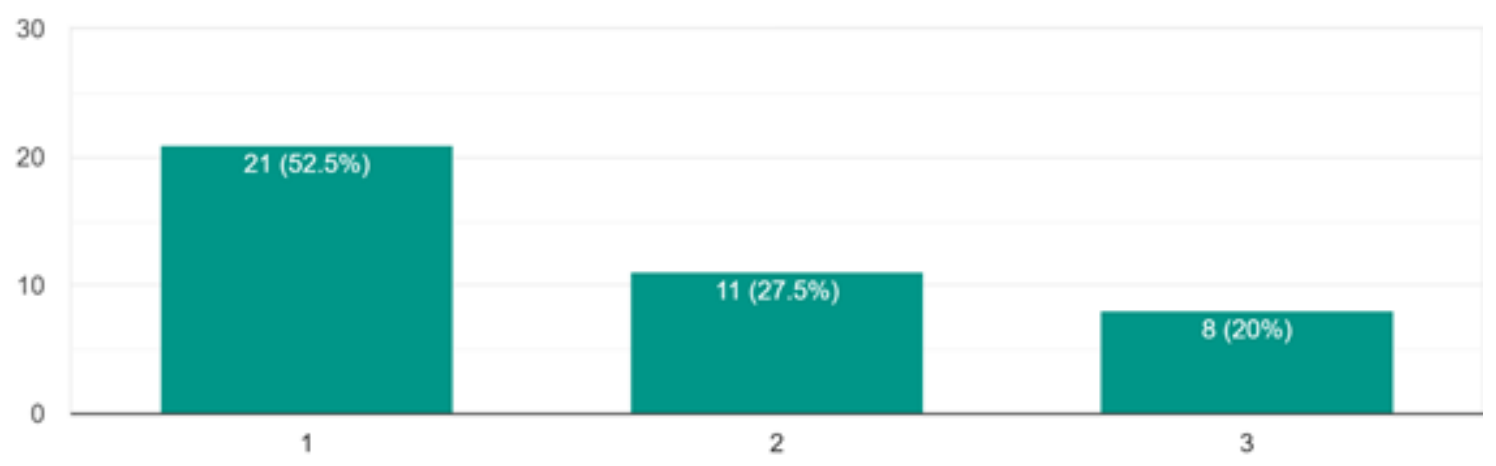

Figure 18. Using gestures as a way of conveying the meaning

Figure 18 shows the majority of the participants are giving positive feedback, $52.5 \%$ have used gestures as a way of conveying their meaning and they found it was useful. $27.5 \%$ of the participants have tried the strategy but still want to learn more on it. Only $20 \%$ of the participants have never tried the strategy. This is a normal situation where everyone usually do when they have no words for it or trying to think of the right words.

\section{I am likely to switch back my own language momentarily if I know my conversation partner can understand what I am saying (Saya mungkin akan ...lan saya dapat memahami apa yang saya katakan) 40 responses}

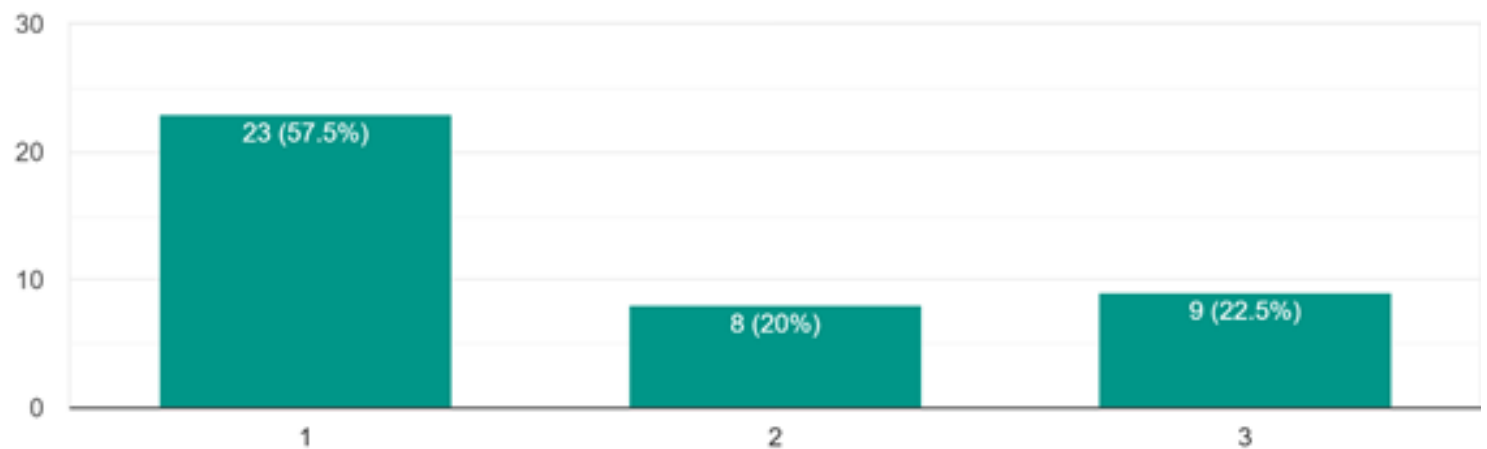

Figure 19. Switch back to their own language momentarily

Figure 19 shows most of the participants, $57.5 \%$ have used the strategy where they switch back to their own language for the time being if they know their conversation partner can understand what they were saying. Meanwhile, $20 \%$ of them have tried the strategy but they still want to learn more on the strategy. $22.5 \%$ of the participants have never tried the strategy. This situation happens especially in a multicultural school where the participants can speak fluently in a few languages and they can understand each other's language.

\section{Implications \& Conclusion}

Thus, after the dissertation research was conducted in the research setting with the consent of the participants, the data collected and analysed had proven that these participants 
showed a greater interest in learning the target language more and more to be a proficient speaker as the native speaker. Therefore, it is implied that in accordance with the questions appealed to the participants during the research dissertation has opened various spaces of improvement in the integration of social learning strategy in improving pupils' speaking skills. The majority of the items (10) has concluded that these participants need to learn deeper on the strategy before being proficient in English Language speaking skills.

The item that has the highest range is the ninth item, which asks on anticipating the upcoming script to be conveyed by the other speaker in a conversation. This is because these participants are still in their primary education and in the process of learning English Language as another spoken language in their daily lives. As they still have a lot of vocabulary to be applied in their daily conversations, they are unable to guess the message that the other speaker is going to convey during the conversation. Thus, by integrating this strategy, they will be able to train themselves in a longer period of time as a 'drilling process' in their speaking skills. This has shown that these participants have pressed a greater awareness on the importance of being able to anticipate the message that they want to convey in any conversation.

Secondly, they feel that they want to learn more by initiating conversations in the new language as often as they can. As they are applying the social learning strategy, Q\&A sessions are advisable where they are going to talk more among their peers. By doing so, they will learn more and more on the proper ways to start any conversation with each other. Not only that, they will be able to start asking questions in a more proper manner as well as in the target language. As they learn more about it, they will get better and better in their English Language proficiency. Not only that, they will be more confident in conversing in the target language.

Next is on getting new words as they are unable to express their messages. By having social learning strategies, ears are always aware of the new words spoken by the other speakers and will be curious on how, where and when to use the particular new vocabulary learnt in their daily lives. Apart from that, they will be able to integrate peer-teaching as they listen to their friends and correct them on the spot for the prosperity of togetherness.

Apart from that, they stressed on asking the natives based on what they do to perform the cultural-based language expressions as well as finding other mediums in expressing their ideas. As we all know, learning can take place anywhere and anytime. Not only that, informal learning takes place and contributes to the increment in the English Language proficiency. when these occur, the non-native speakers are able to follow the proper manners in speaking as the natives. For example, the proper words and word stresses in conversation.

Plus, the ability to speak as the native speaker as well as talking about the concerned topic with the proper vocabulary needs to be revised and sharpen more often in education. As most movies and dramas nowadays are in English Language as well as being written in English subtitle, pupils will be able to assume on the right manners and words to come out with in their conversations. As being perfectly said, they will have to study and discover more so that they have a strong grasp on the particular target language. This will also arouse the conversation and let the pupils engage in throwing out words as they know the manners of using them in their conversations. When this happens, they achieve their aims of being proficient in the particular target language.

Moreover, the empowerment towards the grammatical structures should be strengthened in order to be able to master the particular language as well as being highly proficient. This is because, by doing so, they will be able to correct the others' mistakes and flaws as well as 
increase their confidence level in their daily conversations. This will also enlighten the spirit of teamwork when one is proficine and is able to correct another, more and more of these pupils will be able to converse in the target language better.

However, pupils should not avoid talking on the topics they do not have the language for. As said earlier, education takes place anywhere and anytime. Although they are unable to make words or initiate a discussion about the particular content, they can ask the others in order to have a clearer view on what the topic is all about. By doing so, they can learn as well as discuss the particular topic to gain more knowledge on a larger scale.

As a conclusion, it is undeniable that social learning strategy is vital in improving speaking skills among young learners. It is concluded pupils have to learn speaking skills socially with the community. Speaking skill is crucial to master as it ensures that the convey of message and smoothness of daily conversation takes place well in one's daily life. By identifying the perfect speaking strategies applied to the young learners, teachers can experiment on the various methodologies in order to find out the most suitable way to raise the pupils' proficiency in speaking in the particular target language. By providing a wide repertoire of vocabulary, they will be able to make full use of them and suit those words in their daily conversations. Social learning strategy has found itself the most suitable strategy for speaking skills as speaking takes place in a social environment.

As a non-native speaker, lots of things need to be digested in order to have a full grasp of the target language. The right vocabulary as well as the correct intonation and word stress plays an important role in order for the anticipation of the meaning of the statements to be on the right track as the speaker needs. Confidence and self-esteem will as well increase in line with the development of the particular language empowerment. The best way is to apply the language in daily lives in order to improve day by day. As this is properly immersed in one's life, it will soon develop as if it is like blood that runs in the veins, pumped calmly by the heart throughout the whole parts of the body.

\section{References}

Abdul, M. A. (2011). A Survey of Teaching Strategies in ESL Classroom. Language In India, 11, 313-329. Retrieved from https://www.researchgate.net/publication/273947770_A_Survey_of_Teaching_Strate gies_in_ESL_Classroom.

Abdel, R. E., Mahmoud, A. S., \& Zoubi, S. (2016). Improving English Language Speaking Skills of Ajloun National University Students. International Journal of English and Education, 5(3), 181-195.

https://doi.org/https://www.researchgate.net/publication/306079718_Improving_En glish_Language_Speaking_Skills_of_Ajloun_National_University_Students

Farah, Z., \& Abu, B. R. (2019). Malaysian Rural Secondary School Students' Attitudes towards Learning English as a Second Language. International Journal of Instruction, 12(1), 1141-1156. http://dx.doi.org/10.29333/iji.2019.12173a

Gardner, R. C. (1985). Social Psychology and Second Language Learning: The Role of Attitudes and Motivation. London: Edward Arnold.

Haida, U. H., \& Melor, M. Y. (2018). English as a Second Language (ESL) Learning: Setting the Right Environment for Second Language Acquisition. Tadris: Jurnal Keguruan dan IImu Tarbiyah, 3(2), 207-215. http://dx.doi.org/10.24042/tadris.v3i2.2941 
Ler, E. C. (2012). Cultural factors affecting English proficiency in rural areas. Advances in Language and Literary Studies, 3(1), 1-23. http://dx.doi.org/10.7575/aiac.alls.v.3n.1p.1

Rao, P. S.. (2012). The importance of speaking skills in English classrooms. Alford Council of International English \& Literature Journal (ACIELL), 2(2), 6-18.

Heriansyah. (2012). Speaking problems faced by the English Department students of Syiah Kuala University. Lingua Didaktika Jurnal Bahasa dan Pembelajaran Bahasa, 6(1), 3744.

How, S. Y., Ain, N. A., \& Chan, S. H. (2017). Patterns of dominance of language vitalities among Malaysian students in primary national-type and secondary schools. Indonesian Journal of Applied Linguistics, 6(2), 271-279. http://dx.doi.org/10.17509/ijal.v6i2.4913

Sidhu, G. K., Kaur, S., \& Chi, L. J. (2018). CEFR aligned school-based assessment in the Malaysian primary ESL classroom. Indonesian Journal of Applied Linguistics, 8(2), 452-463. https://doi.org/10.17509/ijal.v8i2.13 
INTERNATIONAL JOURNAL OF ACADEMIC RESEARCH IN BUSINESS AND SOCIAL SCIENCES Vol. 11, No. 6, 2021, E-ISSN: 2222-6990 @ 2021 HRMARS

\section{Appendices}

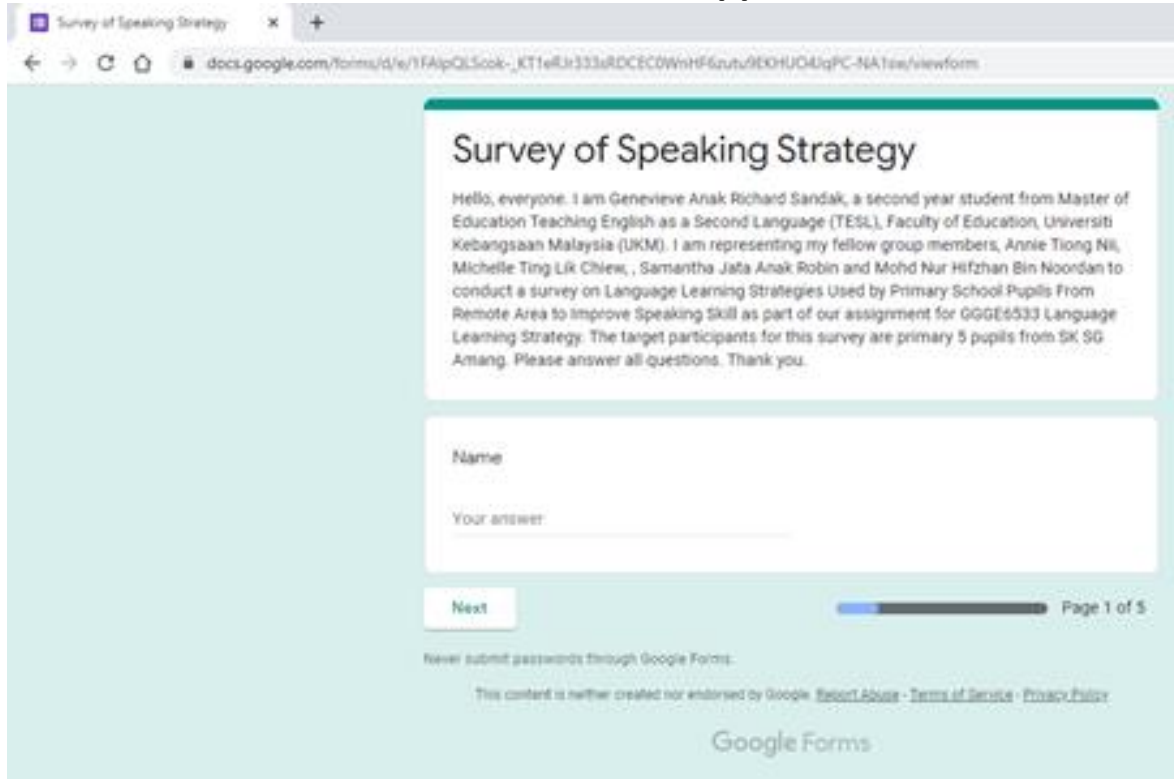

Appendix 1. Short introduction on the group members, title and target group

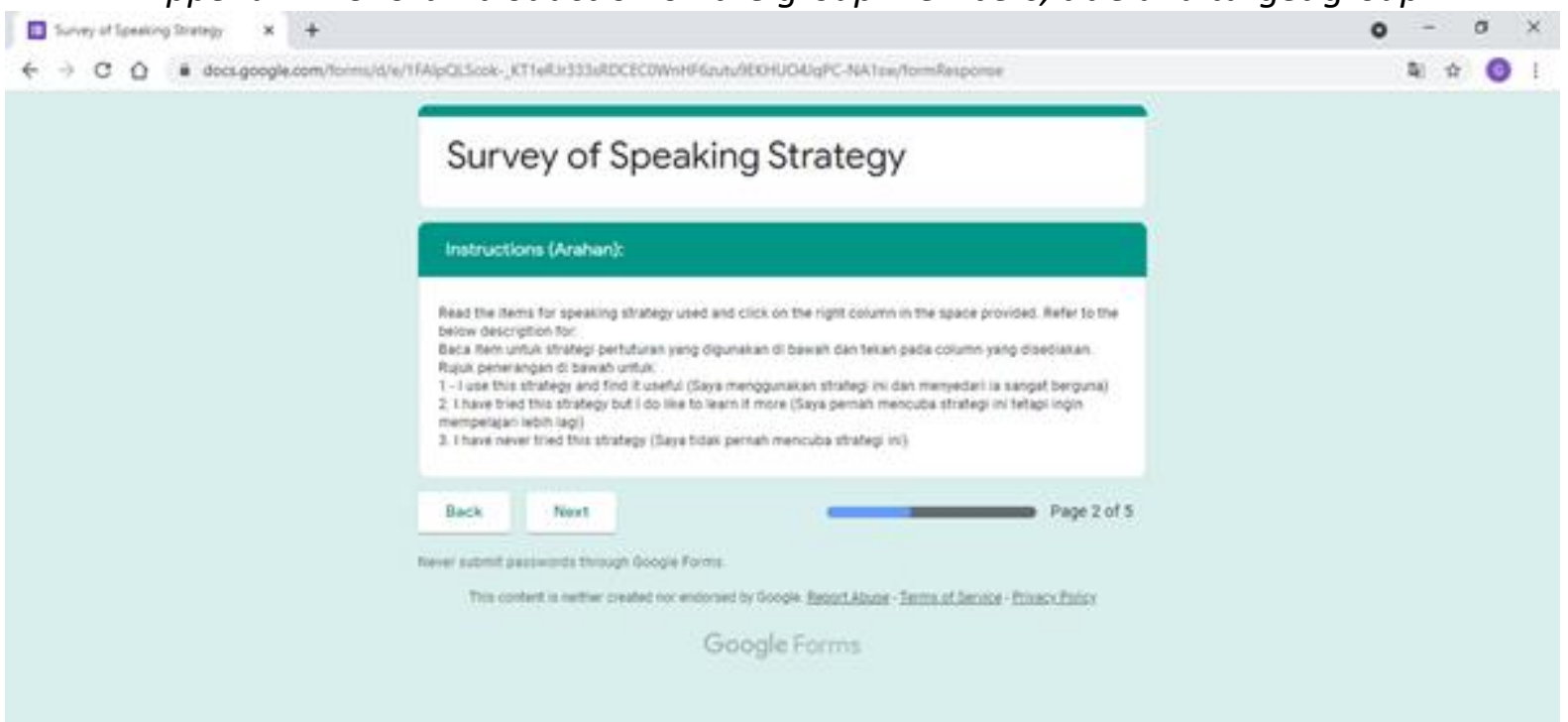

Appendix 2. Instructions and description of the scale 
INTERNATIONAL JOURNAL OF ACADEMIC RESEARCH IN BUSINESS AND SOCIAL SCIENCES

Vol. 11, No. 6, 2021, E-ISSN: 2222-6990 @ 2021 HRMARS

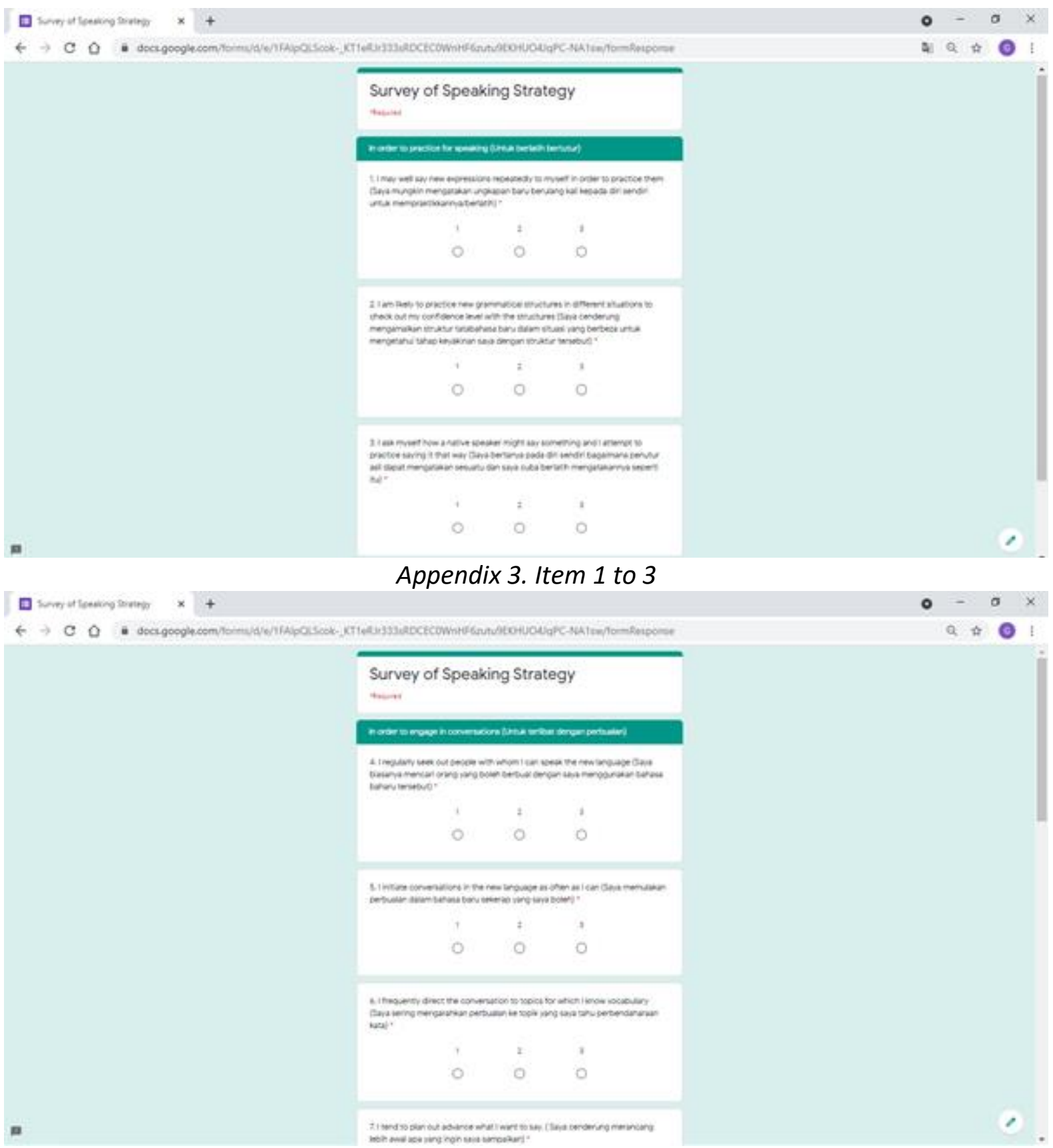

Appendix 4. Item 4 to 6 
INTERNATIONAL JOURNAL OF ACADEMIC RESEARCH IN BUSINESS AND SOCIAL SCIENCES

Vol. 11, No. 6, 2021, E-ISSN: 2222-6990 @ 2021 HRMARS

4

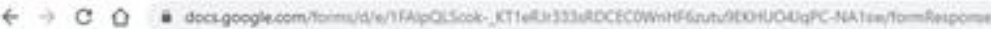

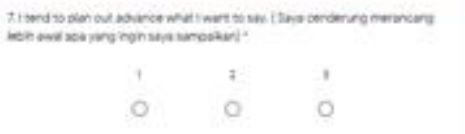

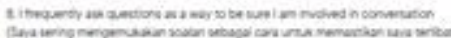

atimentives:

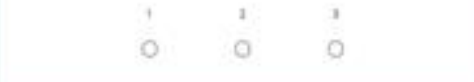

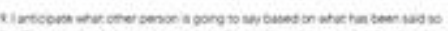

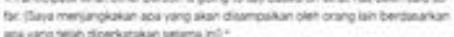

$0 \quad 0 \quad 0$

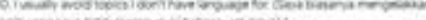

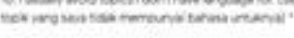

o

Appendix 5. Item 7 to 10

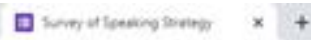

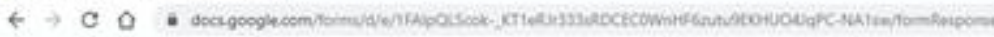

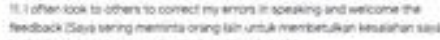

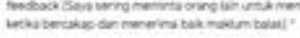

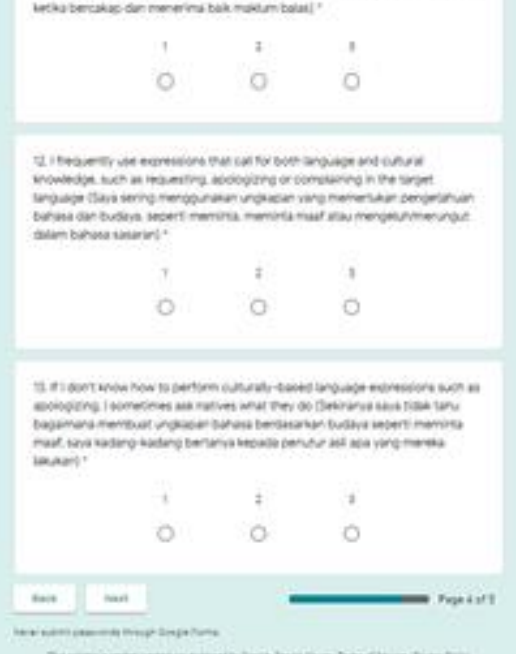

Appendix 6. Item 11 to 12 
INTERNATIONAL JOURNAL OF ACADEMIC RESEARCH IN BUSINESS AND SOCIAL SCIENCES

Vol. 11, No. 6, 2021, E-ISSN: 2222-6990 @ 2021 HRMARS

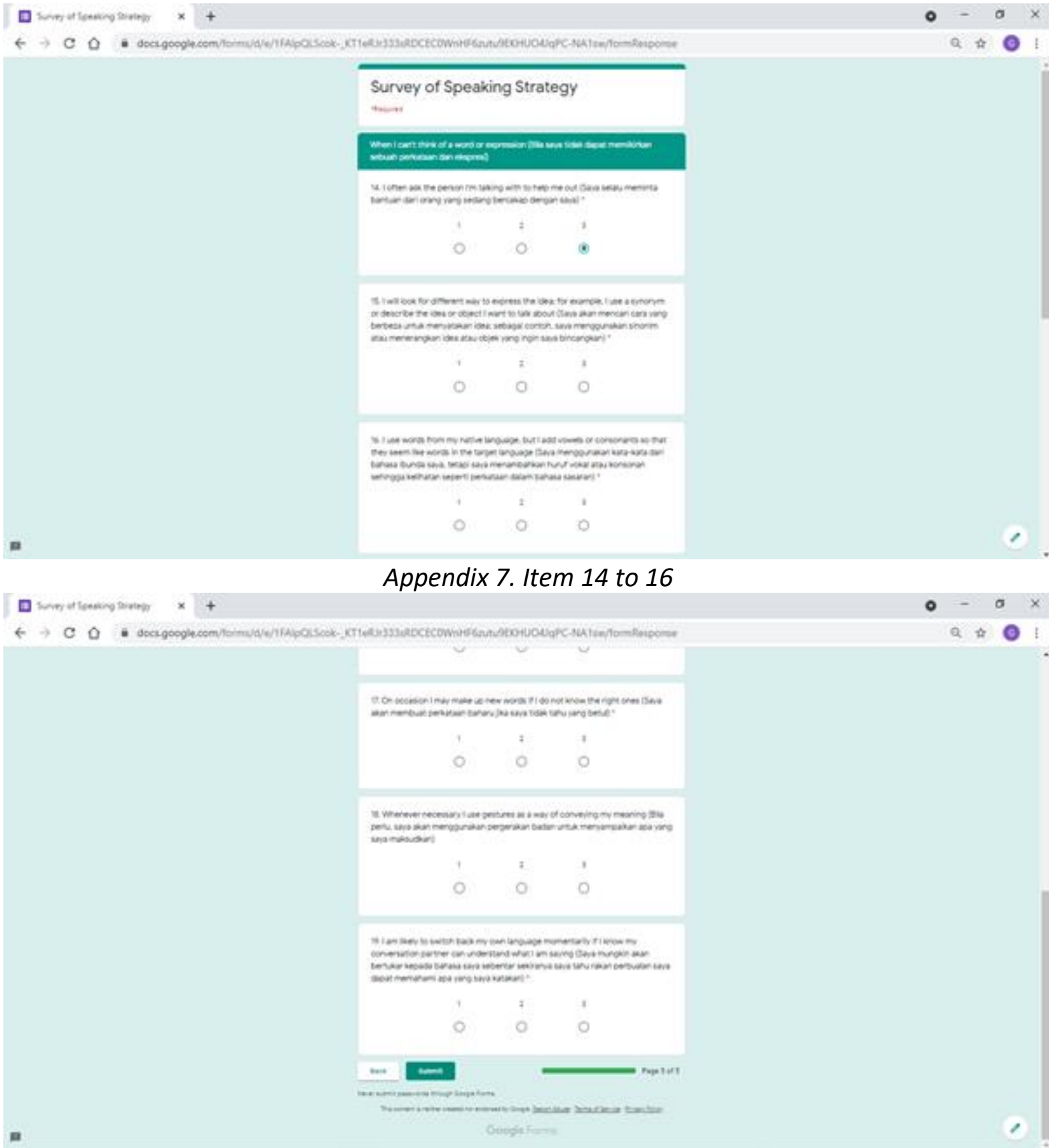

Appendix 8. Item 15 to 19 